UDC 624.014.2.004.15:624.042

\title{
SCIENTIFIC SCHOOL «RELIABILITY OF BUILDING STRUCTURES»: NEW RESULTS AND PRESPECTIVES
}

\author{
Pichugin Sergiy ${ }^{*}$ \\ ${ }^{1}$ Poltava National Technical Yuri Kondratyuk University https://orcid.org/0000-0001-8585-2130 \\ *Corresponding author E-mail: pichugin.sf@gmail.com
}

\begin{abstract}
The article presents the results obtained by scientific school «Reliability of building structures» for the spice of five years $2015-2019$. Some aspects of the general approach to structural reliability assessment have been developed. Current normative calculations of structures were combined with the assessment of their reliability. Engineering methods were developed that allow to take into account an increase snow loading on coverage of building of variable height, to estimate the processes of snow thawing on roofs of the heated buildings and snow laying on cold roofs. It were investigated the specific wind load in the mountainous Carpathian region and loads of travelling cranes of different producers. Reliability of steel structures of trunk pipelines and reinforced concrete beams with carbon-fiber reinforcement has been evaluated. Work features of sheet steel structures were investigated. Construction accidents have been analyzed.
\end{abstract}

Keywords: construction, building, structure, reliability, probabilistic method, load.

\section{НАУКОВА ШКОЛА «НАДІЙНІСТЬ БУДІВЕЛЬНИХ КОНСТРУКЦІЙ»: НОВІ РЕЗУЛЬТАТИ І ПЕРСПЕКТИВИ}

\author{
Пічугін С.Ф. ${ }^{1}$ \\ ${ }^{1}$ Полтавський національний технічний університет імені Юрія Кондратюка \\ E-mail: pichugin.sf@gmail.com
}

\begin{abstract}
Висвітлено наукові результати, одержані науковою школою «Надійність будівельних конструкцій» $3 а 2015$ - 2019 pp. Розвинуто деякі аспекти загального підходу до оцінювання надійності конструкцій. Опубліковано монографію, орієнтовану на практичні розрахунки надійності конструкцій. Діючі нормативні розрахунки конструкцій поєднано 3 оцінюванням їхньої надійності. Розроблено метод визначення ймовірності теплової відмови огороджувальних конструкцій за трьома основними теплотехнічними показниками. Сформовано інженерні методи, які дозволяють ураховувати підвищення снігового навантаження на покриття будівель 3 перепадами висот, оцінювати процеси танення снігу на покрівлях опалюваних будівель та відкладення снігу на холодних покрівлях. Досліджено специфічне вітрове навантаження у гірському Карпатському регіоні та навантаження від мостових кранів різних виробників. Розгорнуто огляд, присвячений важливому питанню сполучення навантажень. Розроблено практичну методику ймовірнісного розрахунку надійності конструкції лінійної частини сталевого магістрального трубопроводу. Розв'язано задачу оцінювання надійності трубопроводу на етапах проектування, спорудження, експлуатації та капітального ремонту - враховувалися кільцеві і поздовжні напруження у трубопроводі, на які впливають деформації випадково-неоднорідної основи, випадкові внутрішній робочий тиск та температурні перепади. Визначено ймовірність відмови трубопроводу для різноманітних умов прокладання. Оціненено надійність залізобетонних балок 3 вуглепластиковим підсиленням. Проведено порівняльний аналіз конструктивних рішень та досліджено особливості роботи листових сталевих конструкцій. Проаналізовано аварії у будівництві. Показано можливі перспективи подальшого розвитку складових проблеми надійності будівельних конструкцій: імовірнісного опису випадкових навантажень, визначення надійності конструктивних елементів, оцінювання безвідмовності складних статично невизначених систем.
\end{abstract}

Ключові слова: будівництво, будівля, конструкція, надійність, імовірнісний метод, навантаження. 


\section{Introduction}

Reliability is an important parameter of any technique. Its content is briefly formulated as «quality in time». Therefore, the problem of ensuring reliability in technology is urgent in today's environment. This problem has some specifics about building objects. Buildings and structures have a long service life. This makes it difficult to predict their reliable operation. Buildings and structures are not numerous or even unique objects. So, they are not suitable for conventional methods of mathematical statistics of mass phenomena. In addition, building loads have a complex random nature. Buildings themselves are complex systems of many elements. Therefore, some issues of building reliability assessment remain unresolved, and further research into the reliability of construction sites is a pressing issue.

\section{Review of the research sources and publications}

Since the 1970s, research into the reliability of buildings and structures has been actively conducted at the National University «Yuri Kondratyuk Poltava Polytechnic» (formerly PoltNTU). Subsequently, this scientific area was organized as one of the scientific schools of the University. In the years that have passed, this scientific school has trained six doctors of science and more than twenty PhDs. The school members wrote dozens of scientific monographs and hundreds of scientific articles, and received many patents for inventions. The results of the research of the scientific school have been reported at many national and international scientific conferences. The Scientific School «Reliability of Building Structures» has high authority in Ukraine and abroad.

The interim summaries of the scientific school's work were published in a collective monograph published in 2010 [1]. Further achievements of the university on the problem of reliability were covered in the thematic issue of the scientific collection of PoltNTU, which was published in 2015 [2]. A general method of the reliability calculating of building structures by the criterion of bearing capacity was developed. This method involves solving the following problems: probabilistic description of loads, mechanical characteristics of materials and joints and other random parameters; development of issues of casual load combinations; assessment of the reliability of structural elements, taking into account the models of their failure; reliability calculation of structural systems, in particular, complex units and redundant systems (RS), taking into account the possible nature of their destruction; quantitative assessment of the reliability of various buildings and structures.

\section{Definition of unsolved aspects of the problem}

The overall level of theoretical results of studies of the building structures reliability is quite high to date. However, the state of development of reliability issues among practitioners remains insufficient. Meanwhile, current codes require them to perform appropriate calculations and estimates. Therefore, we need books and guides with available examples of numerical reliability calculations for different designs. Another drawback is the gap between the reliability calculations and the current method of calculating structures by limit states. We need competent explanations regarding the compatibility of the basic principles of both methods and the probabilistic nature of the parameters of the limitstate technique. The presence and influence on the reliability of the designs of individual high loads with low probability of implementation remains beyond the scope of research. The probabilistic description of atmospheric loads lacks statistics in recent years and climatic characteristics of the mountainous regions of Ukraine. The new capabilities of modern computational complexes for statistical modeling of random loads, in particular, crane loads, are insufficiently exploited.

Problem statement is to highlight the scientific results obtained by the School of Structural Reliability for the five-year period 2015 - 2019 in the above mentioned directions, together with possible prospects for further development of research on the reliability of structural structures.

\section{Basic material and results}

General reliability approach. A voluminous article is published in the scientific journal, which is published in the NDB SKOPUS [3]. The article describes the probabilistic method of the structures reliability estimating. It takes into account the random nature of the loads and the strength of the steel, the compatible action of the loads, the specific nature of the operation and failure of the steel elements, units and steel structural systems as a whole. Based on the developed method, numerical reliability calculations were performed on a wide range of structures such as crane beams, trusses, truss beams, columns and frames. As a result, the coefficients of design codes and the achieved economic effect were substantiated.

The monograph [4] describes the obtained scientific results in more detail. The main difference between this monograph is the orientation to practical calculations of the structures reliability. The volume of such calculations is significantly increased. The text of the book provides more than 40 numerical examples. Theoretical calculations are subordinate in nature and are presented in a reduced volume. They provide the necessary justification and explanation for the calculation examples. In this monograph, the description of probabilistic models used in reliability calculations is substantially supplemented, the provisions of national and foreign normative documents on construction objects reliability are given, it is expanded the range of structural elements for which reliability estimates are obtained. Orientation to practical reliability calculations is associated with a thorough and objective assessment of reliability and the mandatory obtaining of numerical values of reliability indicators, such as failure and uptime probabilities, failure rates, and more. In addition, national codes on the construction sites reliability, introduced in recent years, regulate the quantitative standards of reliability (failure probability, safety characteristics) to be determined in the design. Meanwhile, there 
is a lack of practical guidance in the technical literature, and the book [4] aims to remedy this deficiency to some extent.

During the years mentioned in this article, cooperation with our long-time friend and colleague, DSc., prof. A.V. Perelmuter, a leading employee of SCAD Soft Ltd. (Kyiv), a recognized authority in the field of reliability and computer design calculations. One of the consistent results of our research was the suggestion of a new temporal feature called «mobilization». It shows how much the system is capable of responding to local time (impulse) unexpected perturbation. As a measure of mobilization, it is proposed to take the value obtained by multiplying the reliability index (the number of standards that separate the load mean value from the calculated value) the ratio of the time interval between the emissions of the loading process for the level of the calculated value and the estimated lifetime of the structure. The values of this characteristic are significantly different for the most common loads (snow, wind, crane and their combinations), which are classified by design standards to one class of temporary loads. The lack of mobilization of the structure should lead to increased attention and the use of protective measures, such as heightened control or design decisions. These results have been published in Ukraine [5] and abroad [6, 7].

Current normative calculations of structures were combined with the assessment of their reliability in the monograph [8]. It thoroughly substantiates the main provisions of the method of building structures calculation by limit states. The history, advantages, disadvantages and components of the method, criteria of limit states are covered. The loads acting on the structure and the physical and mechanical characteristics of the structural materials are considered in detail. The nature of work and possible destruction of structures under load are analyzed. Probabilistic analysis of the structures reliability is performed, the prospects for the development of the limit-state method are outlined. Data from domestic and foreign design documents are presented and compared. The monograph is a textbook for students of construction specialty and it is also recommended for graduate students, researchers and engineering staff.

Most reliability calculations use a failure model based on loss of bearing capacity or rigidity. In contrast, a method for determining the probability of thermal failure of envelopes by three main thermo-technical indicators was developed $[9,10]$. Based on minimization of economic losses, the method of normalization of required failure probability level of envelopes by the reduced thermal resistance criterion was proposed.

Research at the scientific school under consideration has traditionally included the following components: development of probabilistic description of loads, evaluation of the reliability of structures and their elements, determination of the reliability of structural systems, implementation of the obtained results. In all the above areas, significant scientific results have been obtained in recent years.
Probabilistic description of loads. The study of loads has always been one of the priority areas of the scientific school «Reliability of building structures». The results of a multi-year study of snow load are outlined in a collective article published in Poland in 2017 [11]. The probabilistic model of the snow accumulation on the roofs with height discontinuity was worked out, the decreasing coefficient for the snow load weight was received and the ways of their application in the designing were elaborated. The proposed approach allows to differentiate the coefficient of roof exploitation conditions $C_{e}$ depending on the roof thermal resistance, and in some cases - significantly to reduce the design snow load values and to give substantial saving of steel. The probabilistic model for impulse stochastic process of snowfall sequence has been developed. According to the data from 132 meteorological stations in Ukraine its statistical characteristics have been found: average annual snowfall amount and exponential distribution of values of one snowfall. The law of intensity distribution of snow melting has been determined experimentally. The territorial zoning map of Ukraine by characteristic values of the snow load on the roofs that emanate heat was developed.

Friendly relations bring together scientists of the scientific school with researchers of reliability and loads from Lviv and Uzhgorod. One of the joint work with them was the study of specific wind load in the mountainous Carpathian region [12]. It was found that wind parameters at the peaks of the Carpathians with absolute marks above $1330 \mathrm{~m}$ (m/s Play) have not been investigated. The analysis of observations on climatic parameters in 1955-2005 at 9 meteorological stations was carried out using 4 directions between the initial meteorological stations: Beregovo - $113 \mathrm{~m}$, Uzhgorod 114,6 m, V. Berezniy - $209 \mathrm{~m}$ and Hoverla Station $2061 \mathrm{~m}$. Formulas of altitude coefficients allowed to calculate the values of summer and winter characteristic wind pressures for the 9 peaks of the Carpathians. On this basis a detailed wind zoning of the mountain district of Transcarpathian region is proposed.

The study of crane loads is a «firm» direction of the Poltava school of reliability, which received important results included in the normative documents. Studies of this problem continued.The comparative analysis of travelling cranes of national and foreign producers was performed [13]. The travelling cranes of concern Demag were taken for consideration among the foreign cranes. The operation conditions of cranes were analyzed according to different codes of practice. The geometrical parameters, load and weight characteristics of overhead cranes were also compared. For the calculation the horizontal and vertical loads of cranes the most unfavorable schemes of location of bridge cranes on the structures of a production building were defined. According to these schemes, the maximum loads on the frame of the building were calculated and the maximum efforts in the crane beams were determined. Using obtained internal efforts the cross sections of crane girders with a span of 6 and $12 \mathrm{~m}$ were calculated. The results 
of the comparison showed the advantages of the modern cranes in materials saving of steel structures of industrial buildings.

Due to the great difficulty of experimental investigations of the crane loads, which have the complicated statistical nature, it is possible to consider analytically such special features of these loads as a trolley approximation, zero crane operation zones and crane impact zones [14]. Nowadays statistical computer modeling can take into account a greater number of variable parameters (position of the cranes in the span, position of the crab on the bridge crane, crane position relative to each other). Comparison of polygons of vertical load on the crane wheel with the analytical results showed that design value of load, calculated according codes DBN realizes very rarely. The further numerical modeling of loads arises an interest for obtaining a more precise definition of the load factors and efforts in the structures of industrial buildings.

An important issue of load combination is devoted to a detailed review (44 pages, 140 bibliographic sources) [15]. The history of formation and development of approaches to a choice of settlement combinations of loadings for check of reliability of building designs is considered. It is underlined parallelism of researches of domestic and foreign scientists. Data about rationing of this problem and about the works which formed the basis of design codes are cited. It is noted that the problem of load combination is not fully solved and requires further research, in particular, in the following areas: development of correlated coupling of random loads; taking into account combinations of actual random load distributions; a detailed description of the specific features of the loads, closely related to the technology of production and features of structures operation - crane, technological, useful, etc.; taking into account logical relationships between download options; solution of the problem of combination or the limit states of the second group taking into account the operational values of the loads.Reliability assessment of trunk pipeline designs. Particular attention was paid to these structures due to the fact that Ukraine is one of the main hydrocarbon transiters to the countries of Eastern and Western Europe. The significant volumes of transit of oil, gas and their derivatives through the territory of Ukraine determine its strategic position in the energy security of Europe. For this purpose a powerful system of gas and oil pipelines of Ukraine is used, which should have high reliability. The conducted researches were devoted to this problem, namely to development of probabilistic methods of reliability estimation of linear parts of main pipelines. The choice of linear parts as the object of study is due to their considerable length, significant effects of climatic and soil conditions and the high risk of accidents with severe environmental consequences. The scientific results obtained on this subject formed the basis of two theses $[16,17]$, a series of articles [18] and two monographs [19, 20].

The developed methods of probabilistic estimation of reliability indicators take into account: pipeline construction; diameter and thickness of pipe walls; statistical characteristics of steel strength; load from internal pressure; characteristics of soils in which the underground pipeline is laid; temperature effects; real corrosion damage to pipe walls. The listed impact factors were presented in the form of random variables and random processes. This opened up the possibility of developing methods for estimating the probability of failure of pipelines under different combinations of loads and impacts, in different soil conditions and design situations. The performed calculations of the real pipelines made it possible for the first time to estimate their level of reliability and to analyze the influence of the calculation factors on the failure probability of the linear parts. The effect of corrosion damage on the level of reliability of the linear parts of pipelines is also taken into account. The issues of planning of repair of pipelines with corrosion damages are developed. As a whole, the complex of problems related to the reliable operation of the linear parts of the pipelines in real climatic and geological conditions, taking into account the initial imperfections and corrosion damages, has been solved.

Reliability estimation of reinforced concrete beams with carbon-plastic external strengthening. Strengthening of building structures is an important scientific and technical problem, actuality of that grows presently. Feature of this building branch during the last years is appearance, research and active introduction in practice of structures strengthening of new modern materials being high strengthening and operating characteristics. Ones of such materials are composite materials on the basis of carbon fibre (FAP). Their application in the system of external reinforcement can exemplify by composite materials of row of trade marks, intended for the increase of durability and of longevity reinforced concrete, concrete, brick and stone structures. For the receipt of reliability estimations we used the worked out reception with the substitution of probabilistic parameters in the deterministic decisions of durability of reinforced concrete beams. Taken into account thus, that most random arguments of reserve of bearing strength of reinforced concrete beams can be reasonably described by a normal law (by distribution of Gausse), in particular, durability of concrete, armature, carbon-plastic, and also row of loadings (permanent, technological, crane etc.). The reinforced concrete beams of rectangular section were considered with the single stretched armature with strengthening of carbonplastic. The reliability estimation of reinforced concrete beams with carbon-plastic external strengthening was worked out. It was shown, what strengthening promotes reliability of beams considerably [3].

Investigation of features of work of sheet steel structures. In collaboration with National Aviation University staff, design and construction organizations, research into the operation and reliability of these specific structures has been initiated. The paper [21] deals with summarizing research concerning analytical technique of calculation of vertical cylindrical capacities for grain storage under the influence of unsymmetrical wind influences. In particular, the analysis of vertical stiffeners' work was conducted and illustrated the body deformation for high and low capacities, depending on the 
number of rigid elements. Considering the character of the wind load's influence, there were also made propositions considering defining normal and tangential strains in cross-section, longitudinal directions and also radial, circular and longitudinal displacements, accordingly to the general theory, was made. In addition, capacities with different edges' fortification are considered, for example, strengthened by absolutely rigid circle, free or fixed by elastic circle. General assessment of the total deflected mode of the capacity's construction was made, depending on the number of decomposition coefficients, which were put in calculation. Conclusions are accompanied with graphic isometric understandings, which were obtained on the basis of practical calculation.

Next paper [22] deals with the using of high strength steel for constructions of vertical silo capacities. It was analyzed the most widespread trademarks of steel that were used for manufacturing of vertical cylindrical silos for grain storage. It were experimentally tested mechanical and chemical features of series of examples of high strength steel of European and American manufacturers, which were used for making of the body's sheet panels. The checking calculation of storage capacity with the diameter of $11 \mathrm{~m}$ from shaped corrugated sheet of different thickness was made. It was shown critical factors of the body sheets, bolted joints and vertical stiffeners of the silos. It was mentioned reasonable conclusions according to the using of the concerned material for getting economically rational project decisions.

It was analyzed the structural solutions of steel silos for bulk material [23]. The design elements of the silo and the silo with cone and flat bottom were described. The general characteristics of metal silos for bulk materials, their classification by the type of housing structure and the advantages and disadvantages were given. The possibility of storage of bulk materials in cylindrical shells was analyzed depending on the type of construction. The history of occurrence of structures of spiral-fold silos was considered. The set of equipment for the construction of the housing of the spiral-fold silos was given, the step-by-step process of formation of the folding lock and features of the installation process were presented. The analysis of the structure was made and the advantages and disadvantages of spiral-fold silos were determined.

Structures such as tanks, silos, bins are very responsible structures. Their failures lead to great economic and environmental damage. Therefore, it is important to analyze the accidents of such structures. The work [24] presents the statistics of accidents of steel vertical tanks with a detailed review of the established causes and consequences of its occurrence. Information on accidents was collected on the basis of Internet sources, literature on this issue, as well as scientific publications of previous years. It also were investigated the reasons for the emergence of the need to study this issue, developed statistics materials for past years. On the basis of the collected and studied material, a chart of the percentage of the accident type at the high-security facility from $2009-2019$ has been created. As a result of the work done, the most common types of accidents for steel vertical tanks were identified and appropriate conclusions were made.

The reliability of redundant systems. One of the significant achievements of the Poltava School of Reliability is the solution of the problem of reliability of statically indeterminate (redundant) systems [1 - 4]. The redundant structure failure estimation is a very complicated problem as depends upon the system complexity. Redundant structure failures occur after some member failures in the form of transmission to different workable states. These states match different designing schemes with various probabilistic parameters. The important thing is that determination of the elements significance in the reliability of redundant frames [25]. For this the probabilistic method of limit equilibrium is applied. All possible mechanisms of structural failure are considered. The influence of each section on the work of the frame as a whole is taken into account. Stochastic strength and load characteristics are used in the calculations. The graphs of specific contributions of individual sections and the most probable mechanisms of destruction are presented. The task was to align the impact of the frame sections without reducing the specified reliability, but it is possible to obtain a design with the same specific contributions, which is most economically justified. Specific contributions are increased or decreased as necessary to obtain a design with equal probability of failure. The method provides an opportunity to obtain optimal designs and the use of modern software systems for static calculation. Recommendations for the design of these structures have been developed. It is proposed to use the reliability coefficient of redundant steel structures.

Analyze of accidents in construction. The problem of buildings and structures crashes remains relevant in the current environment. Cases of destruction of construction sites with significant economic losses and human casualties make the issue more detailed. That is why the School of Building Reliability has studied building accidents in recent years [26]. On the basis of collected and processed information the accidents classification in the building was presented, depending on the building erection stage. The article gives a detailed description and analysis of such cases in the construction. The collection of information on accidents was carried out using various information sources: Internet resources, literary sources, scientific works and information from world-wide journalistic services. The findings are presented over the last ten years and cover worldwide construction incidents. The material is systematized and presented in the table form. The study results are the created accidents classification with the probability of their occurrence, which can be used later in the design of buildings and structures, in order to predict the various types of accidents in the construction.

Next paper covers the consequences of accidents at buildings and structures during the construction and acceptance in operation [27]. Attention is focused on the frequency of repetition of this type of accidents, using the graph of the structures' operation stages. The work 
describes and analyzes such incidents related to construction. The corresponding diagrams are constructed. The result of the study is the relevant conclusions about the typification of accidents during construction and their regularities. The most common causes of accidents are identified, which allow to obtain more detailed study of the problem and further provide for cases of such accidents at the construction site. Attention is focused on the dependence of the construction's quality on the level of the country's welfare. In addition, the conclusions contain the main tasks in the solution of this problem and ways of their implementation.

Implementation in design standards. Research findings of our University in the field of reliability have been highly praised and implemented in a number of state regulations. This is the highest level of implementation, as these standards are used by all designers throughout Ukraine. One of the normative documents developed in recent years is DSTU B B.2.6-210:2016 «Assessment of the technical condition of used steel structures» [28]. Several of our proposals are included in this national standard, including recommendations for testing the load-bearing capacity of beams with damage in the form of horizontal distortion, classification of technical conditions of structures and editorial amendments. Over the last five years, standards have slowed down: a few years ago, we have been preparing with our participation new revisions to the standards for load and reliability. I, together with. DSc. A.V. Perelmuter even participated in a discussion with DSc., prof. A.I. Lantuh-Lyashchenko (National Transport University) [29]. He argued that the existing DBN «General Principles for the Reliability of Building Structures» had serious drawbacks and had to be radically corrected. We opposed this proposal, because these rules are the only ones in the territory of the former USSR, they have stood the test of time for ten years, regulate a complex system for ensuring the reliability and safety of construction objects and require only partial amendments and references to new regulations.

Application of scientific principles in the humanitarian sphere. The preparation of the publications, partially mentioned in the list of literature, allowed to gain some experience in writing scientific books. This experience was successfully applied when writing a monograph of another humanitarian profile [30]. This book is dedicated to the famous Poltava artist Viktor Baturin (1937 - 1993). A prominent exposition artist, Honored Artist of Ukraine, he was the head of unique exhibitions creating of the Poltava Museums Ivan Kotlyarevsky, Panas Mirny, Mykola Gogol, Anton Makarenko, the Kiev Theater Museum, the Ochakov Military History Museum. For some time he was also the chief artist of Poltava, he developed the coat of arms of the city, created a monument to the fallen Cossacks and designed the Ukraine Pavilion at the World's Fair in Stuttgart (Germany). The author of the article was the author of the book. Working on the book required the combined efforts of museum workers, artists, people who knew Victor Baturin. By his 80th birthday, the book had been published, presented in a museum I.P. Kotlyarevsky and free distributed. Subsequently, the author of the article made presentations of the book in Poltava museums and libraries, spoke at the scientific conferences PNPU, dedicated to the memory of the outstanding teacher A.S. Makarenko, published an article in the scientific professional collection of PNPU.

\section{Conclusions}

Summarizing the work of the School of Structural Reliability for the five years 2015 - 2019, it should be noted that significant scientific results were obtained in this short period of time. They contributed to the defense of doctoral and $\mathrm{PhD}$ theses, the publication of five scientific monographs and 56 scientific articles, the publication of six textbooks, the participation in scientific conferences in the United Kingdom (London), Finland (Cottbus), Poland (Krakow, Green Gora), Azerbaijan (Baku), Kazakhstan (Taraz), as well as in Ukraine (Kiev, Odessa, Kharkiv, Dnipro, Rivne, Kropyvnytskyi), have acted as an official opponent for two doctoral and two PhD theses. At the same time, the questions for further prospective research, mentioned above in the article, remain unresolved.

\section{References}

1. Надежность строительных конструкиий. Работа научной школы професора Пичугина С.Ф.: сборник научных трудов (2010). Полтава: ООО «АСМИ».

2. Пічугін, С.Ф. (2015). Наукова школа «Надійність будівельних конструкцій»: досягнення і перспективи. 3бірник наукових прачь. Серія: Галузеве машинобудування, будівниитво, 1(43), 3-16.

3. Pichugin, S.F. (2018) Reliability Estimation of Industrial Building Structures. Magazine of Civil Engineering, 83(7), 24-37.

http://10.18720/MCE.83.3

4. Пічугін, С.Ф. (2016). Розрахунок надійності будівельних конструкцій. Полтава: ТОВ «АСМІ».

5. Перельмутер, А.В., Пичугин, С.Ф. (2014). Об одной характеристике надежности строительных объектов. Металеві конструкиії, 2 (20), 109-117.

1. Reliability of building structures. Works of S.F. Pichugin's Scientific School: collection of scientific articles (2010). Poltava: Publishing House «ASMI».

2. Pichugin, S.F. (2015) Scientific School «Reliability of Building Structures»: Achievements and Perspectives. Academic journal. Series: Industrial Machine Building, Civil Engineering, 1 (43), 3-16.

3. Pichugin, S.F. (2018) Reliability Estimation of Industrial Building Structures. Magazine of Civil Engineering, 83(7), 24-37.

http://10.18720/MCE.83.3

4. Pichugin, S.F. (2016). Reliability Calculation of Building Structures. Poltava: Publishing House «ASMI».

5. Perelmuter. A.V., Pichugin. S.F. (2014). About One Characteristic of Building Construction Reliability. Metal Structures, 2 (20), 109-117. 
6. Перельмутер, А.В., Пичугин, С.Ф. (2014). Об оценке уязвимости строительных конструкцій. Инженерностроительный журнал, 5(49), 5-14.

https://engstroy.spbstu.ru/article/2014.49.1/

7. Perelmuter, A.V., Pichugin S.F. (2017). On One Safety Characteristic of Buildings. Journal of Civil Engineering and Architecture Research. 5 (4), 2035-2044.

8. Перельмутер, А.В., Кабанцев, О.В., Пичугин, С.Ф. (2019). Основы метода расчетных предельных состояний. Москва: Издательство СКАД СОФТ и АСВ.

9. Семко, В.О. (2017). Надійність несучих та огороджувальних конструкиій із сталевих холодноформованих тонкостінних профілівю. (Автореф. дис. ... докт. техн. наук. ПолтНТУ, Полтава.

10. Pichugin, S., Semko, V., Leshchenko, M. (2017). Probabilistic analysis of thermal performance of the wall from light-gauge thin-walled steel structures. Збірник наукових прачь. Серія: Галузеве машинобудування, будівниитво, 1(48), 144-155.

11. Pichugin, S.F., Dryzhyruk, Yu.V., Popovich, N.M., Chernetska, I.V. (2015). The features of snow loads on building roofs. Technical Transactions, Budownictwo Zeszyt 2-B (12), 441-449.

http://dx.doi.org/10.4467/2353737ХCT.15.149.4186

12. Пічугін, С.Ф., Кінаш, Р.І., Гук, Я.С. (2017). Методика визначення характеристичних значень середнього $\mathrm{i}$ максимального вітрових тисків в липні і січні для 9 вершин Карпат із районуванням території Закарпатської області. Промислове будівництво та інженерні споруди, 1 , 35-44.

13. Pichugin, S., Patenko, I., \& Maslova, S. (2018). Comparative Analysis of Loads from the Travelling Cranes of Different Producers. International Journal of Engineering \& Technology, 7(3.2), 36-39.

http://dx.doi.org/10.14419/ijet.v7i3.2.14372

14. Pichugin S., Patenko Yu. (2019).To the Assessment of Vertical Crane Load. International Journal for Computational Civil and Structural Engineering, 15(1), 131-139.

15. Перельмутер, А.В., Пичугин, С.Ф. (2015). Расчетные сочетания нагрузок для проверки надежности конструкций (обзор). Збірник наукових пращь Украйнського. інституту сталевих конструкцій імені В.М. Шимановського, 15, 4-47.

16. Зима, О.С. (2014). Надійність сталевої конструкиії магістрального трубопроводу. (Автореф. дис. канд. техн. наук). ПолтНТУ, Полтава.

17. Винников, П.Ю. (2017). Надійність лінійної частини підземного магістрального трубопроводу на випадково-неоднорідній основі: Автореф. дис. канд. техн. наук. Полтава: ПолтНТУ.

18. Pichugin, S., Zyma, O. \& Vynnykov, P. (2016). Reliability level of the buried Main Pipelines Linear Part. Recent Progress in Steel and Composite Structures, 551-558.

19. Пічугін, С.Ф., Пашинський, В.А., Зима, О.С., Винников, П.Ю., Біла, Ж.Ю. (2018). Надійність лінійних частин магістральних трубопроводів. Полтава: Астрая.

20. Онищенко, В.О., Винников, Ю.Л., Зоценко, М.Л., Пічугін, С.Ф. та ін. (2018). Ефективні конструктивнотехнологічні рішення об'єктів транспортування нафти $i$ нафтопродуктів у складних інженерно-геологічних умовах. Полтава: ФОП Пусан А.Ф.

21. Pichugin, S., Makhinko, N. (2018). Features of the Silo Capacities' Calculation at the Unsymmetrical Wind Load. International Journal of Engineering \&Technology. 4.8(7), 2226.

http://dx.doi.org/10.14419/ijet.v7i4.8.27208
6. Perelmuter, A.V., Pichugin, S.F. (2014). About an estimation of building structures vulnerability. Magazine of Civil Engineering, 5(49), 5-14.

https://engstroy.spbstu.ru/article/2014.49.1/

7. Perelmuter, A.V., Pichugin, S.F. (2017). On One Safety Characteristic of Buildings. Journal of Civil Engineering and Architecture Research. 5 (4), 2035-2044.

8. Perelmuter, A.V., Kabantsev, O.V., Pichugin, S.F. (2019). Method Bases of Calculation by Limit States: monograph. Moscow: Publishing Houses SCAD SOFT and ASV.

9. Semko, V.O. (2017). Reliability of bearing and enclosing structures of steel cold-formed thin-walled profiles. (Master's thesis). PoltNTU, Poltava.

10. Pichugin, S., Semko, V., Leshchenko, M. (2017). Probabilistic analysis of thermal performance of the wall from light-gauge thin-walled steel structures. Academic Journal. Series: Industrial Machine Building, Civil Engineering, 1(48), 144-155.

11. Pichugin, S.F., Dryzhyruk, Yu.V., Popovich, N.M., Chernetska, I.V. (2015). The features of snow loads on building roofs. Technical Transactions, Budownictwo Zeszyt 2-B (12), 441-449.

\section{http://dx.doi.org/10.4467/2353737XCT.15.149.4186}

12. Pichugin, S.F., Kinash, R.I., Huk, Y.S. (2017). Methods of Determining Characteristic Values of Average and Maximum Wind Pressures in July and January for 9 Peaks of the Carpathians with Zoning of the Territory of the Transcarpathian Region. Industrial Construction and Engineering, 1, 35-44.

13. Pichugin, S., Patenko, I., \& Maslova, S. (2018). Comparative Analysis of Loads from the Travelling Cranes of Different Producers. International Journal of Engineering \& Technology, 7(3.2), 36-39.

http://dx.doi.org/10.14419/ijet.v7i3.2.14372

14. Pichugin S., Patenko Yu. (2019).To the Assessment of Vertical Crane Load. International Journal for Computational Civil and Structural Engineering, 15(1), 131-139.

15. Perelmuter, A.V., Pichugin, S.F. (2015). Calculation Load Composition for the Verification of Structural Reliability (review). Collection of scientific works of Ukrainian Structural Steel Institute Shimanovsky, 15, 4-47.

16. Zyma, O.E. (2014). Reliability of main pipeline steel structure. (Master's thesis). PoltNTU, Poltava.

17. Vynnykov, P.Y. (2017). Reliability level of the buried main pipelines linear part on the stochastic soil base. (Master's thesis). PoltNTU, Poltava.

18. Pichugin, S., Zyma, O. \& Vynnykov, P. (2016). Reliability level of the buried Main Pipelines Linear Part. Recent Progress in Steel and Composite Structures, 551-558.

19. Pichugin, S.F., Pashynskyi. V.A., Zyma. J.E., Vynnykov. P.Y. \& Bila. Z.Y. (2018). Reliability of Main Pipelines Linear Parts. Poltava: Publishing House «ASTYA».

20. Onyshchenko, V.O., Vynnykov, Yu.L., Zotsenko, M.L., Pichugin, S.F. and oth. (2018). Effective Constructive-technological Solutions of Oil and Oil Products Transportation in Complicated Geotechnical Conditions. Poltava: FOP Pusan A.F.

21. Pichugin, S. \& Makhinko, N. (2018). Features of the Silo Capacities' Calculation at the Unsymmetrical Wind Load. International Journal of Engineering \&Technology. 4.8(7), 22-26.

htp://dx.doi.org/10.14419/ijet.v7i4.8.27208 
22. Pichugin, S., Makhinko, N. (2019). High-strength steel grades application for silos structures. Збірник наукових праць. Серія: Галузеве машинобудування, будівництво, 1(52), 51-57.

https://doi.org/10.26906/znp. 2019.52.1674

23. Пічугін, С.Ф., Оксененко, К.О. (2019). Конструктивні рішення сталевих силосів для сипучих матеріалів. Академічна й університетська наука: результати та перспективи: Збірник наукових праць за матеріалами XII Міжнародної науково-практичної конферениії. Полтава: ПолтНТУ

24. Pichugin, S.F., Klochko, L.A. (2019). Accidents analysis of steel vertical tanks. Сучасні методи і проблемно-орієнтовані комплекси розрахунку конструкиій $і$ їх застосування у проектуванні і навчальному прочесі: тези доповідей III Міжнародної науково-практичної конферениії, Київ: ТОВ «Софія-А» ЛТД.

25. Pichugin, S.F., Chichulin, V.P., Chichulina, K.V. (2019). Determination of the elements significance in the reliability of redundant frames. International Journal for Computational Civil and Structural Engineering, 15(3), 109-119.

26. Pichugin, S.F., Klochko, L.A. (2019). Accidents features in construction. Збірник наукових праць. Серія: Галузеве машинобудування, будівництво, 1(52), 91-101.

https://doi.org/10.26906/znp.2019.52.1681

27. Pichugin, S.F., Dmytrenko, L.A. (2018). International Journal of Engineering \&Technology, 3.2 (7), 311-315.

http://dx.doi.org/10.14419/ijet.v7i3.2.14426

28. ДСТУ Б В.2.6-210:2016 (2016). Очінка технічного стану будівельних сталевих конструкиій, що експлуатуються. Київ: Мінрегіон України.

29. Перельмутер, А.В., Пічугін, С.Ф. (2018). Щодо нової редакції ДБН В.1.2-14-2009. Промислове будівництво та інженерні споруди, 2, 33-34.

30. Пичугин, С.Ф. (2017). Виктор Батурин. Художник и его музеи. Полтава: ООО «АСМИ.
22. Pichugin, S. \& Makhinko, N. (2019). High-strength steel grades application for silos structures. Academic Journal. Series: Industrial Machine Building, Civil Engineering, 1(52), 51-57.

https://doi.org/10.26906/znp. 2019.52.1674

23. Pichugin, S.F., Oksenenko, K.O. (2019). Structural Solutions of Steel Silos for Bulk Material: Academy and University Science: Results and Perspectives: Collection of scientific works by materials of XII International Scientificpractical Conference. Poltava: PoltNTU.

24. Pichugin, S.F., Klochko, L.A. (2019). Accidents analysis of steel vertical tanks. Modern Methods of Modeling and Analysis of Structures. Software for Civil and Structural Engineering, Design and Education: Report theses of III International Scientific Conference. Kyiv: TOV «Sofia-A» LTD.

25. Pichugin, S.F., Chichulin, V.P., Chichulina, K.V. (2019). Determination of the elements significance in the reliability of redundant frames. International Journal for Computational Civil and Structural Engineering, 15(3), 109-119.

26. Pichugin, S.F., Klochko, L.A. (2019). Accidents features in construction. Academic Journal. Series: Industrial Machine Building, Civil Engineering, 1(52), 91-101.

https://doi.org/10.26906/znp.2019.52.1681

27. Pichugin, S.F., Dmytrenko, L.A. (2018). International Journal of Engineering \&Technology, 3.2 (7), 311-315.

http://dx.doi.org/10.14419/ijet.v7i3.2.14426

28. DSTU B.2.6-210:2016 (2016). Assessment of the technical condition of used steel structures. Kyiv: Minregion of Ukraine.

29. Perelmuter, A.V., Pichugin, S.F. (2018). About New Reduction of DBN B.1.2-14-2009. Industrial Construction and Engineering, 2, 33-34.

30. Pichugin, S.F. and oth. (2017). Victor Baturin. The Artist and his Museums. Poltava: Publishing House «ASMI». 